\title{
Factors Influencing Students' Likelihood to Purchase Electronic Textbooks
}

\author{
Robert W. Stone and Lori Baker-Eveleth \\ University of Idaho, Moscow, ID, USA
}

\author{
rstone@uidaho.edu leveleth@uidaho.edu
}

\begin{abstract}
Technological advances touch multiple aspects of an individual's life. One such example is the use of information technology to provide online books. Online books have been introduced in education in the form of electronic textbooks (e-texts). The research question examined here is among those students who have purchased or used an e-text, what factors motivate their willingness or likelihood to purchase an e-text? A model and hypotheses linking the factors of usefulness, arousal, ease of use, value, and effort to the likelihood to purchase an electronic textbook are presented. The model and hypotheses are tested using a sample of 529 student responses to a questionnaire distributed in a mid-sized university in the western United States. Using these responses, the model and hypotheses are tested using a structural equations approach and maximum likelihood estimation. The results indicate that an e-text's usefulness, its ease of use, and students' arousal regarding the e-text significantly impact students' likelihood to purchase an e-text. However, the student's perceived value of an e-text and how worthwhile their effort to search for low price textbooks did not impact these students' likelihood to purchase an electronic textbook. A discussion and conclusions are also presented.
\end{abstract}

Keywords: electronic textbooks, factors influencing purchase, ease of use, usefulness, technology.

\section{Introduction}

Technological advances touch multiple aspects of an individual's life. One such example is the use of information technology to provide online books. Digital books or e-book adoptions have been predicted to grow at a much higher rate than what has actually occurred (Thomas, 2007). Some reasons for this slow growth include a lack of an industry standard for the technology, transferability among technologies and the lack of a clear, consistent business model (Dillion, 2001). Another issue affecting growth is digital text resolution which influences eye strain and fatigue. Bennett and Landoni (2005) identified that screen resolution is not compatible with paper resolution requiring the brain and eyes to work harder to achieve comprehension leading to eye

Material published as part of this publication, either on-line or in print, is copyrighted by the Informing Science Institute. Permission to make digital or paper copy of part or all of these works for personal or classroom use is granted without fee provided that the copies are not made or distributed for profit or commercial advantage AND that copies 1) bear this notice in full and 2) give the full citation on the first page. It is permissible to abstract these works so long as credit is given. To copy in all other cases or to republish or to post on a server or to redistribute to lists requires specific permission and payment of a fee. Contact Publisher@InformingScience.org to request redistribution permission. strain. Consistently, Liu (2005) found that individuals often prefer to read print copies rather than a digital version when reading for sustained periods of time. This may well indicate that e-books are suited for references and searching text rather than pleasure or more sustained reading (Thomas, 2007). In conclusion, it appears that an e-book is a better delivery method, not a better way to read (Coleman, 2004). 
Electronic books have been introduced in education in the form of electronic textbooks (e-texts). Often these e-texts are web-based, digital replicas of print textbooks, or downloadable PDF's (Falc, 2013). E-texts are considered a learning object since they support learning, are reusable, and provide a building block for digital course content (Ritzhaupt, 2010). The structure of an etext allows a student to interact with the content in many ways. Examples include for reference material, practice problems, or as a test environment depending on the needs of the student. A typical textbook can be used in different learning contexts making it reusable (Mogharreban \& Guggenheim, 2008). Noyes and Garland $(2005,2006)$ found that undergraduate students continue to prefer learning with printed text rather than digital. Users have expressed a willingness to use an e-text, but that its usability is too poor to be a close substitute for a print text (Bennett \& Landoni, 2005; Buzzetto-More, Sweat-Guy, \& Elobaid, 2007). This holds true when the price of the e-text is significantly lower than a print version (Carlson, 2005). Liu (2005) found that $80 \%$ of students surveyed prefer print text to digital text in order to understand the text meaning. In this same study undergraduate students found digital text less interesting and the authors less credible (Liu, 2005). The University of California Libraries conducted a study and found that $58 \%$ of undergraduate students preferred print books (Falc, 2013) while a study at Northwest Missouri found a $40 \%$ reduction in studying because of the e-textbook format (Young, 2009). A final expressed concern is that students frequently need to be tied to a monitor when reading digital text (Carlson, 2005).

In spite of the above problems with e-texts, there are a variety of advantages, such as lower costs, better accessibility, and improved currency of content (Cavanaugh, 2004). The cost advantage to students is reasonably clear since e-texts can be rented, available for free or for half the price of a traditional textbook (Baker-Eveleth, Miller, \& Tucker, 2011; Falc, 2013). Public school districts are also moving to e-texts as a cost saving mechanism (Tomassini, 2012) although a recent higher education study showed the difference in savings between e-texts and traditional texts is insignificant (DeSantis, 2012).

Internet availability has created an opportunity for easy access to digital resources and e-texts. Access refers to the ability to easily identify and read a variety of related content quickly. Electronic book readers and tablet devices have also affected the access to digital resources by providing portability, search-ability, and content tagging (Choi, 2012; Peek, 2012; Weisberg, 2011). Searching and tagging on a device mimics a traditional textbook with highlighting, page tagging, and writing comments in the margins (Lai \& Chang, 2011). Improved currency of content is due to the ability of publishers to update content more frequently between print editions of a textbook. This is particularly advantageous in dynamic content areas (Cavanaugh, 2004).

Given the mix of advantages and disadvantages of students purchasing and using e-texts, what motivates a student's likelihood to purchase an e-text? Specifically, among students who have used an e-text, what factors influence their willingness to purchase an electronic textbook? That is the question addressed in the research presented below. The research is presented in the following order. First, the literature including the model and hypotheses are presented. These are followed by a presentation of the method including the sample and measures. The results are presented next followed by discussion and conclusions.

\section{The Literature}

Accepting a technology depends on the belief that the technology benefits the adopter (Bates \& Khasawneh, 2007). If a technology is perceived to be useful, an individual is more likely to adopt and use it in the future (Henry \& Stone, 2001). A technology whose use is mandatory may possess inflated degrees of use, but the perception of its usefulness is still present (Iivari, 2005). Rai, Lang, and Welker (2002) defined "quasi-volitional IT use" as un-mandated use of the system but not completely volitional because of social pressure and subjective norms in the environment. 
This means that an individual may not be required to use the system but the influences in the context of its use suggest the individual should use it.

In a classroom setting, some choices students have are volitional in that students decide whether or not to participate. Other of their choices are nonvolitional; students have no apparent choice as participation is perceived to be required. In the case of textbooks, one might expect that required textbooks are nonvolitional. Professors may list on a syllabus required textbooks implying students have no choice regarding the selected text. However, today's university students have resources beyond the bookstore and are comfortable "shopping around" for textbooks using the Internet. Thus, regardless of whether or not the professor lists an electronic textbook or a traditional paper textbook as required, students usually have the option of purchasing the textbook in whatever form they prefer.

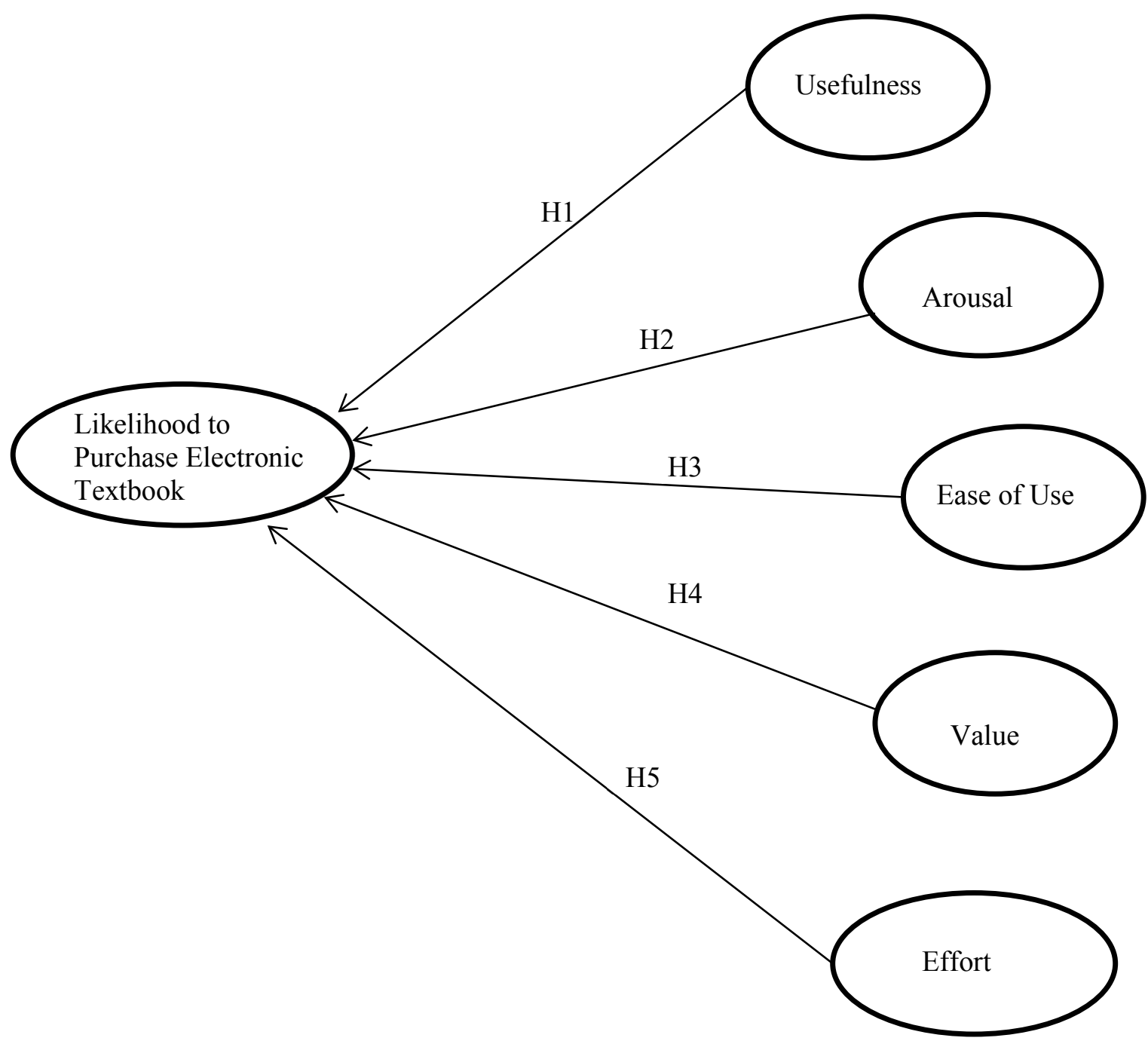

Figure 1: The Standardized Results for the Estimated Model

There are five factors hypothesized to influence student's willingness to purchase an e-text. The premise underlying the model is based on the concept that positive consumer feelings increase the likelihood of a purchase while irritants decrease this likelihood. In the context of retail design environments, this has been shown by d'Astous (2000). It is not much of a stretch in logic to link product features to this impact on likelihood to purchase. In the context of complementary and non-complementary bundles of product features, Chernev (2005) illustrated those assortments of 
product features impact the probability of purchase. Similarly, Tsiotsou (2006) showed that perceptions of product quality and overall satisfaction influence purchase intentions. Following the above logic, the presented model links e-text features or factors to students' likelihood to purchase an e-text. Each factor, supporting literature, and formal hypothesis is presented below in its own subsection. The model itself is shown in Figure 1.

\section{Usefulness}

A characteristic of an e-text that should impact students' willingness to purchase is whether or not the e-text fits the way the student studies. Bradshaw (2005) noted that e-texts provide opportunities to employ a variety of styles to fit learners' needs. However, Thurston (2000) stated that learners often need to adapt to the use of an e-text. Similarly, Schoch, Teoh, and Kropman (2006) found that many readers of an e-text have to change their study habits to cope with using an etext. From these research works, it makes sense that if an e-text is perceived to fit the way a student studies, this would have a positive impact on the perceived usefulness of the e-text.

Similarly, usefulness is viewed in this research as helping a student become more successful academically. Kirkwood and Price (2005) found that two keys to a student's comprehension when using an e-text is understanding how the technology works and its benefits to the student. Improved academic performance is one such benefit. More generally, outcome expectancy, also often referred to as perceived usefulness has been shown to impact behavior in a variety of settings (Bandura, 1986; Henry \& Stone, 2001). The role of usefulness is summarized by hypothesis 1.

Hypothesis 1 (H1): Usefulness has significant, positive impacts on the likelihood to purchase an electronic textbook.

\section{Arousal}

Arousal in this research refers to the interest and stimulation students perceive in the purchase and use of an e-text. A predetermination of interest or prior experience can be an indication of interest and stimulation of students toward their use of an e-text. Birnbaum (2004) found that students' differences in computer experience appear to influence their differences in satisfaction with e-texts. The ability to access digital content is related to computer experience and satisfaction. Computer experience differences may well be linked to physiological arousal regarding an e-text and its use. The result is summarized in hypothesis 2 shown below.

Hypothesis 2 (H2): Arousal has significant, positive impacts on the likelihood to purchase an electronic textbook.

\section{Ease of Use}

Ease of use for an e-text as defined in this research in the spirit of easy for the student to do whatever they desire with the e-text. Birnbaum (2004) found that, when comparing graduate students to undergraduate students, the graduates liked using the e-text and found it easy to use and navigate. However, the undergraduates preferred a print version because they found the e-text cumbersome to use. Additionally, Kirkwood and Price (2005) found that one key to student comprehension using an e-text is an understanding of how the technology works. These implications are summarized by hypothesis 3 .

Hypothesis 3 (H3): Ease of use has significant, positive impacts on the likelihood to purchase an electronic textbook. 


\section{Value and Effort}

One of the frequently cited advantages to purchasing an e-text is the substantially lower price or cost relative to a printed textbook. Specifically, Cavanaugh (2004) states that one reason for students to adopt and use an electronic textbook is cost. With this backdrop, we consider two measures and hypotheses related to these cost advantages. The first measure is labeled value and focuses on the price and quality combination students face when deciding among the various textbook options, including print and digital versions. Lau (2008) identified a reason for slow adoption of e-texts as students' unclear perceptions of the e-texts' value. The second measure is labeled effort and measures the students' attitudes regarding the efficacy of searching for low cost textbooks. The measure effort is really an attempt to evaluate the willingness of students to expend effort to identify and exploit any cost savings inherent in purchasing e-texts.

Hypothesis 4 (H4): Value has significant, positive impacts on the likelihood to purchase an electronic textbook.

Hypothesis 5 (H5): Effort has significant, positive impacts on the likelihood to purchase an electronic textbook.

\section{The Method}

\section{The Sample}

The data to empirically test the model were collected using a survey of students at a mid-sized university in the western United States. The questionnaire was web-based and developed and distributed using Qualtrics. Qualtrics is a commercial, web-based software product for the development and distribution of questionnaires. A university listserv provided the email addresses to which the questionnaire was distributed. A total of 11,957 students received an email invitation to complete the questionnaire and 1382 responses were received producing a $11.56 \%$ response rate. Among these 1382 responses, 646 respondents or $47 \%$ reported prior purchase or use of an electronic textbook. However, only 529 of these were usable due to missing questionnaire responses to the items used to measure the model's constructs. These 529 responses compose the sample.

\begin{tabular}{|c|c|c|}
\hline \multicolumn{3}{|c|}{ Table 1: The Sample Characteristics } \\
\hline Age & & \\
\hline Average & 23.39 & \\
\hline Minimum & 18 & \\
\hline Maximum & 49 & \\
\hline Gender & Frequency & Percentage \\
\hline Male & 221 & $41.78 \%$ \\
\hline Female & 308 & $58.22 \%$ \\
\hline Total & 529 & $100.00 \%$ \\
\hline Daily Computer Use & Frequency & Percentage \\
\hline Less than 1 hour & 3 & $0.58 \%$ \\
\hline 1-2 hours & 45 & $8.64 \%$ \\
\hline 3-5 hours & 255 & $48.94 \%$ \\
\hline
\end{tabular}




\begin{tabular}{|c|c|c|c|}
\hline 6-9 hours & \multicolumn{2}{|l|}{157} & $30.13 \%$ \\
\hline Greater than 9 hours & \multicolumn{2}{|l|}{61} & $11.71 \%$ \\
\hline Total & \multicolumn{2}{|l|}{521} & $100.00 \%$ \\
\hline $\begin{array}{l}\text { Have own desktop comput- } \\
\text { er }\end{array}$ & \multicolumn{2}{|l|}{ Frequency } & Percentage \\
\hline Yes & \multicolumn{2}{|l|}{201} & $38.29 \%$ \\
\hline No & \multicolumn{2}{|l|}{324} & $61.71 \%$ \\
\hline Total & \multicolumn{2}{|l|}{525} & $100.00 \%$ \\
\hline Have own laptop computer & \multicolumn{2}{|l|}{ Frequency } & Percentage \\
\hline Yes & \multicolumn{2}{|l|}{497} & $94.49 \%$ \\
\hline No & \multicolumn{2}{|l|}{29} & $5.51 \%$ \\
\hline Total & \multicolumn{2}{|l|}{526} & $100.00 \%$ \\
\hline \multicolumn{4}{|l|}{ GPA } \\
\hline \multicolumn{2}{|l|}{ Average } & \multicolumn{2}{|l|}{3.36} \\
\hline \multicolumn{2}{|l|}{ Minimum } & \multicolumn{2}{|l|}{0.97} \\
\hline \multicolumn{2}{|l|}{ Maximum } & 4.00 & \\
\hline College & \multicolumn{2}{|l|}{ Frequency } & Percentage \\
\hline Agriculture \& Life Sciences & \multicolumn{2}{|l|}{56} & $10.63 \%$ \\
\hline Art \& Architecture & \multicolumn{2}{|l|}{23} & $4.36 \%$ \\
\hline Business \& Economics & \multicolumn{2}{|l|}{120} & $22.77 \%$ \\
\hline Education & \multicolumn{2}{|l|}{49} & $9.30 \%$ \\
\hline Engineering & \multicolumn{2}{|l|}{82} & $15.56 \%$ \\
\hline $\begin{array}{l}\text { Letters Arts \& Social Scienc- } \\
\text { es }\end{array}$ & \multicolumn{2}{|l|}{120} & $22.77 \%$ \\
\hline Natural Resources & \multicolumn{2}{|l|}{31} & $5.88 \%$ \\
\hline Science & \multicolumn{2}{|l|}{46} & $8.73 \%$ \\
\hline Total & \multicolumn{2}{|l|}{527} & $100 \%$ \\
\hline
\end{tabular}

The sample characteristics are reported in Table 1 based on these 529 responses, except for the occasional missing response to a respondent demographic item. Over $58 \%$ of the respondents were female and the average respondent age was 23.39 years with a minimum of 18 years and a maximum of 41 years. For the amount of daily computer use, the most frequently reported category at nearly $49 \%$ of the respondents was 3 to 5 hours per day. Six to nine hours per day was the second most frequently reported category at just over $30 \%$. Nearly $62 \%$ of the responding students reported that they do not own a desktop computer while over $94 \%$ said they have a laptop computer. The self-reported grade point average was 3.36 with a range from 0.97 to 4.00 . The students were also asked to self-report the college in which they were enrolled. The most fre- 
quently reported colleges were business and economics and letters arts and social sciences at almost $23 \%$ each. The next most often reported college was engineering at almost $16 \%$.

\section{The Measures}

The measures of the model's constructs were formed by collecting student responses to a series of questionnaire items. For all items, the students were given a statement and a scale upon which to respond. For the two questionnaire items measuring the likelihood to purchase e-texts, respondents were given a five-point Likert-type scale with anchors of 1-Very Unlikely; 2- Unlikely; 3Undecided; 4-Likely; and 5-Very Likely. All the remaining items used scales with anchors of 1Strongly Disagree; 2-Disagree; 3- Neither Agree or Disagree; 4-Agree; and 5-Strongly Agree.

\begin{tabular}{|c|c|c|c|c|c|c|}
\hline \multicolumn{7}{|c|}{$\begin{array}{c}\text { Table 2: The Indicants, Measures, and Psychometric Properties } \\
\text { From the Confirmatory Factor Analysis }\end{array}$} \\
\hline Indicant and Measures & Paths & Paths & Paths & Paths & Paths & Paths \\
\hline \multicolumn{7}{|l|}{ Usefulness (Reliability 0.96; Shared Variance 79\%) } \\
\hline $\begin{array}{l}\text { 1. I am pleased with how electronic textbooks facili- } \\
\text { tate my studying. }\end{array}$ & 0.80 & & & & & \\
\hline $\begin{array}{l}\text { 2. } \begin{array}{l}\text { Electronic textbooks fit well with how I read and } \\
\text { study. }\end{array}\end{array}$ & 0.79 & & & & & \\
\hline \multicolumn{7}{|l|}{ Using an electronic textbook helps...... } \\
\hline 3. Me do a better job in my classes. & 0.93 & & & & & \\
\hline 4. Improves my quality of academic work. & 0.94 & & & & & \\
\hline 5. $\quad$ Makes me more successful in class. & 0.93 & & & & & \\
\hline 6. Improve my academic performance. & 0.94 & & & & & \\
\hline \multicolumn{7}{|l|}{\begin{tabular}{|l|} 
Arousal (Reliability 0.88; Shared Variance 72\%) \\
\end{tabular}} \\
\hline \multicolumn{7}{|l|}{ I have found using an electronic textbook to be..... } \\
\hline 7. $\quad$ Stimulating. & & 0.83 & & & & \\
\hline 8. Meaningful. & & 0.93 & & & & \\
\hline 9. Intuitive. & & 0.77 & & & & \\
\hline \multicolumn{7}{|l|}{ Ease of Use (Reliability 0.85 ; Shared Variance $74 \%$ ) } \\
\hline 10. I find electronic textbooks to be easy to use. & & & 0.80 & & & \\
\hline $\begin{array}{l}\text { 11. I find it easy to do what I want it to do using an } \\
\text { electronic textbook. }\end{array}$ & & & 0.92 & & & \\
\hline \multicolumn{7}{|l|}{$\begin{array}{l}\text { Likelihood to Purchase Electronic Textbook (Relia- } \\
\text { bility 0.93; Shared Variance 87\%) }\end{array}$} \\
\hline $\begin{array}{l}\text { 12. The likelihood of purchasing an electronic textbook } \\
\text { is...very unlikely; unlikely; undecided; likely; very } \\
\text { likely. }\end{array}$ & & & & 0.90 & & \\
\hline $\begin{array}{l}\text { 13. My willingness to buy an electronic textbook } \\
\text { is...very unlikely; unlikely; undecided; likely; very } \\
\text { likely. }\end{array}$ & & & & 0.96 & & \\
\hline
\end{tabular}




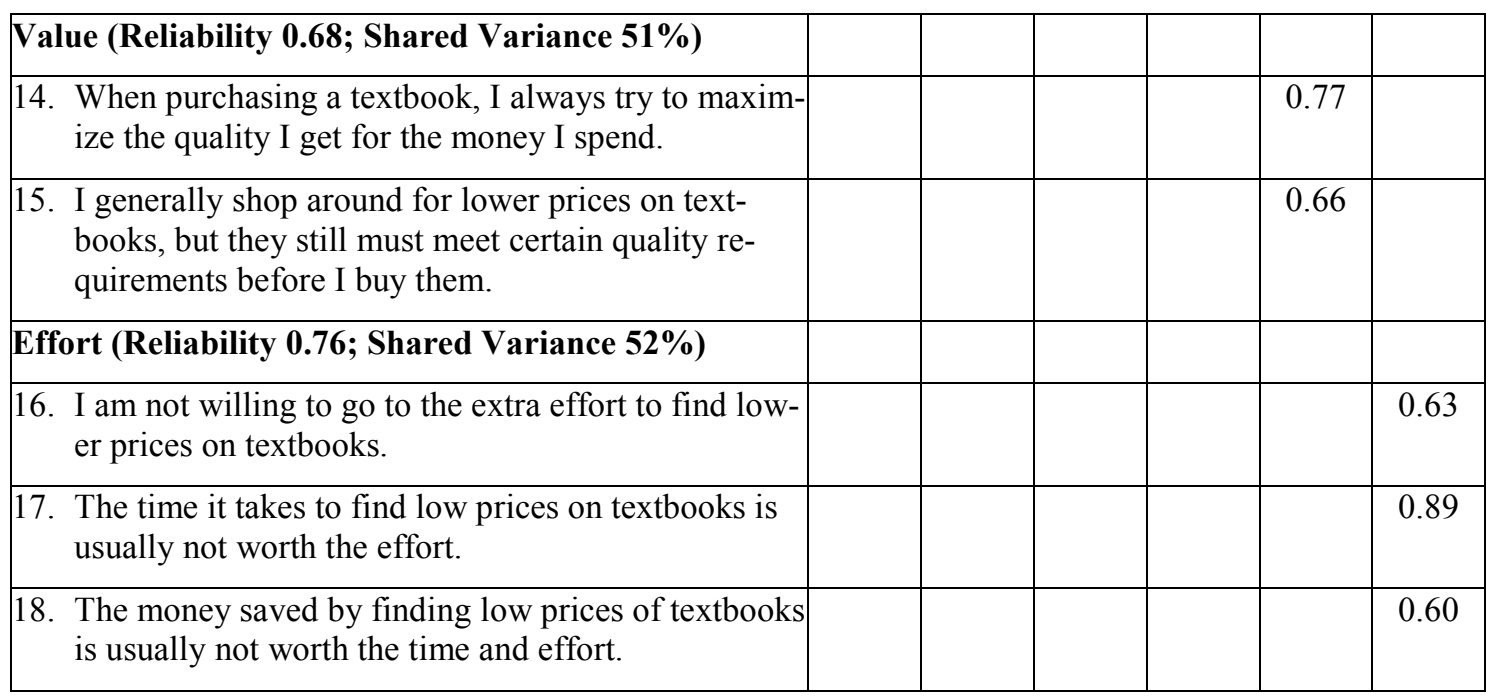

The items forming the measures and the psychometric properties of the measures are shown in Table 2. The results from a confirmatory factor analysis generated the values reported in Table 2 . The confirmatory factor analysis allowed all measures to pair-wise correlate and each measure to be reflective in its indicants. The estimation was performed using procedure Calis in PC SAS version 9.2 and maximum likelihood estimation. Calis is a structural equations modeling procedure within PC SAS. It is similar in intent to such software packages as LISREL, Amos, and Bentler's EQS. The use of a structural equations modeling approach allows for the examination of each indicant's influence on its measure of the constructs in the model. The fit of the model to the data was good as illustrated by a goodness of fit index of 0.87 , the parsimonious goodness of fit index of 0.68 , and the root mean square residual and standardized root mean square residual of 0.097 . In addition the Bentler comparative fit index was 0.94 and Bollen's normed and non-normed indexes were 0.91 and 0.94 , respectively. The chi-square statistic was 585.70 with 120 degrees of freedom and was significant at a $1 \%$ level. The normed chi-square was 4.88 . Finally, the root mean square error of approximation was 0.09 with a $90 \%$ confidence interval ranging from 0.083 to 0.097 .

The standardized path coefficients to the indicants of the measures in the confirmatory factor analysis were used to calculate the reliability coefficients and shared variances of these measures. The reliability coefficient was calculated as the sum of these standardized path coefficients squared divided by this sum plus the sum of the indicant measurement error. The shared variance was calculated by summing the squared standardized path coefficients divided by this sum plus the sum of the indicant measurement error.

The usefulness measure had six items developed based on a measure in Stone and Baker-Eveleth (2013). The standardized path coefficients ranged from 0.79 to 0.94 . The shared variance for this measure was $79 \%$ and its reliability coefficient was 0.96 . The arousal measure contained three questionnaire items modified from Baker-Eveleth et al. (2005) with standardized path coefficients of $0.77,0.83$, and 0.93 . The measure had a reliability coefficient of 0.88 and shared variance of $72 \%$. Ease of use was developed using two questionnaire items (Stone \& Baker-Eveleth, 2013). The standardized path coefficients were 0.80 to 0.92 . The reliability coefficient was 0.85 with shared variance of $74 \%$. The likelihood to purchase an electronic textbook measure was built using two items developed from the work of Stone and Baker-Eveleth (2013). The standardized path coefficients for these items were 0.90 and 0.96 with a reliability coefficient of 0.93 . The shared variance for the likelihood to purchase an electronic textbook measure was $87 \%$. The value measure was constructed from two questionnaire items developed specifically for this re- 
search. It had standardized path coefficients of 0.77 and 0.66 . Its reliability coefficient was 0.68 and its shared variance was $51 \%$. Effort was the final measure and it too was an original scale developed for this research. Its path coefficients were $0.63,0.60$, and 0.89 . The reliability coefficient was 0.76 and the shared variance $52 \%$.

Based on the magnitudes of the standardized path coefficients, it can be argued that item reliability is satisfied (Rainer \& Harrison, 1993). The estimated path coefficients ranged from 0.60 to 0.96. In terms of measure reliability, all the measures except value demonstrate adequate values of this trait (Rainer \& Harrison, 1993). This measure had a reliability coefficient of 0.68 , slightly below a generally accepted cutoff level of 0.70 (Nunnally, 1978). The remaining measures had reliability coefficients ranging from 0.76 to 0.97 . These results indicate that the measures, with the possible exception of value, satisfy convergent validity (Igberia \& Greenhaus, 1992; Rainer \& Harrison, 1993).

\begin{tabular}{|l|c|}
\hline \multicolumn{1}{|c|}{ Table 3: The Squared Correlations Among the Measured Based on the } \\
Confirmatory Factor Analysis \\
\hline \multicolumn{1}{|c|}{ Measure Pair } & Squared Correlation \\
\hline Effort-Usefulness & 0.003 \\
\hline Effort-Arousal & 0.004 \\
\hline Effort-Ease of Use & 0.0004 \\
\hline Effort-Value & 0.11 \\
\hline $\begin{array}{l}\text { Fits The Way Study-Likelihood to Purchase } \\
\text { Electronic Textbook }\end{array}$ & 0.00 \\
\hline Usefulness-Arousal & 0.60 \\
\hline Usefulness-Ease of Use & 0.64 \\
\hline $\begin{array}{l}\text { Usefulness- Likelihood to Purchase Electronic } \\
\text { Textbook }\end{array}$ & 0.52 \\
\hline Usefulness- Value & 0.002 \\
\hline Arousal-Ease of Use & 0.49 \\
\hline Arousal- Value & 0.00 \\
\hline $\begin{array}{l}\text { Arousal- Likelihood to Purchase Electronic } \\
\text { Textbook }\end{array}$ & 0.48 \\
\hline Ease of Use- Value & 0.001 \\
\hline $\begin{array}{l}\text { Ease of Use- Likelihood to Purchase Electronic } \\
\text { Textbook }\end{array}$ & 0.00 \\
\hline Value -Likelihood to Purchase Electronic & \\
\hline & \\
\hline
\end{tabular}

Discriminant validity was also examined by comparing, for each pair of measures, their squared correlation to their individual percentage of shared variance. If discriminant validity is satisfied, the items within a measure share greater common variation among themselves than between the two measures. In other words, discriminant validity is satisfied for each measure pair if the indi- 
vidual measures' percentages of shared variance are greater than the squared correlation between the two measures (Fornell \& Larcker, 1981). All the squared correlations were calculated using the confirmatory factor analysis results. Discriminant validity is satisfied for all pairs of measures. All the squared correlations are reported in Table 3 and the percentages of shared variance in Table 2.

These results provide modestly mixed results regarding the psychometric properties for the measures. The value measure is on the cusp of convergent validity, but does satisfy discriminant validity. All the other measures satisfy both convergent and discriminant validity and hence construct validity (Hair, Anderson, Tatham, \& Black, 1992). The value measure requires additional examination and refinement, which is not extremely surprising as it was used for the first time in this research effort.

\section{The Results}

\section{The Estimated Model}

The model displayed in Figure 1 was defined by the measures and their indicants and estimated using a structural equations approach. The estimation was done in PC SAS version 9.2 using procedure Calis and maximum likelihood estimation. The questionnaire items were used as reflective indicants of their respective measures and numbered the same as in Table 2.

\begin{tabular}{|l|l|}
\hline \multicolumn{2}{|c|}{ Table 4: The Statistics Summarizing the Fit of the Model to the Data } \\
\hline Statistic & Value \\
\hline Goodness of Fit Index & 0.87 \\
\hline Parsimonious GFI & 0.68 \\
\hline Chi-square Statistic & $577.62^{* *}$ \\
\hline \multicolumn{1}{|c|}{ Degrees of Freedom } & 120 \\
\hline Normed Chi-square Statistic & 4.81 \\
\hline Root Mean Square Residual (RMSR) & 0.06 \\
\hline Standardized RMSR & 0.06 \\
\hline $\begin{array}{l}\text { Root Mean Square Error of Approximation } \\
\text { (RMSEA) }\end{array}$ & 0.09 \\
\hline RMSEA 90\% Confidence Interval & 0.082 to 0.097 \\
\hline Bentler's Comparative Fit Index & 0.94 \\
\hline Bollen Normed Index & 0.91 \\
\hline Bollen Non-normed Index & 0.94 \\
\hline
\end{tabular}

** Statistically significant at a $1 \%$ level.

Table 4 displays several statistics summarizing the quality of the fit between the model and the data. The goodness of fit index of was 0.87 and the parsimonious goodness of fit 0.68 . The chisquare statistic was 577.62 (significant at a 1\% level) with 120 degrees of freedom and its normed or relative counterpart was 4.81 . The root mean square residual and the standardized root mean square residual were both 0.06 . The root mean square error of approximation was 0.09 with a $90 \%$ confidence interval ranging from 0.082 to 0.097 . Bentler's comparative fit index was 0.94 
and the Bollen normed and non-normed indexes were 0.91 and 0.94 , respectively. These fit values, while mixed, are sufficient for us to conclude that the fit is acceptable fit (Hair et. al, 1992; Hooper, Coughlan, \& Mullen, 2008).

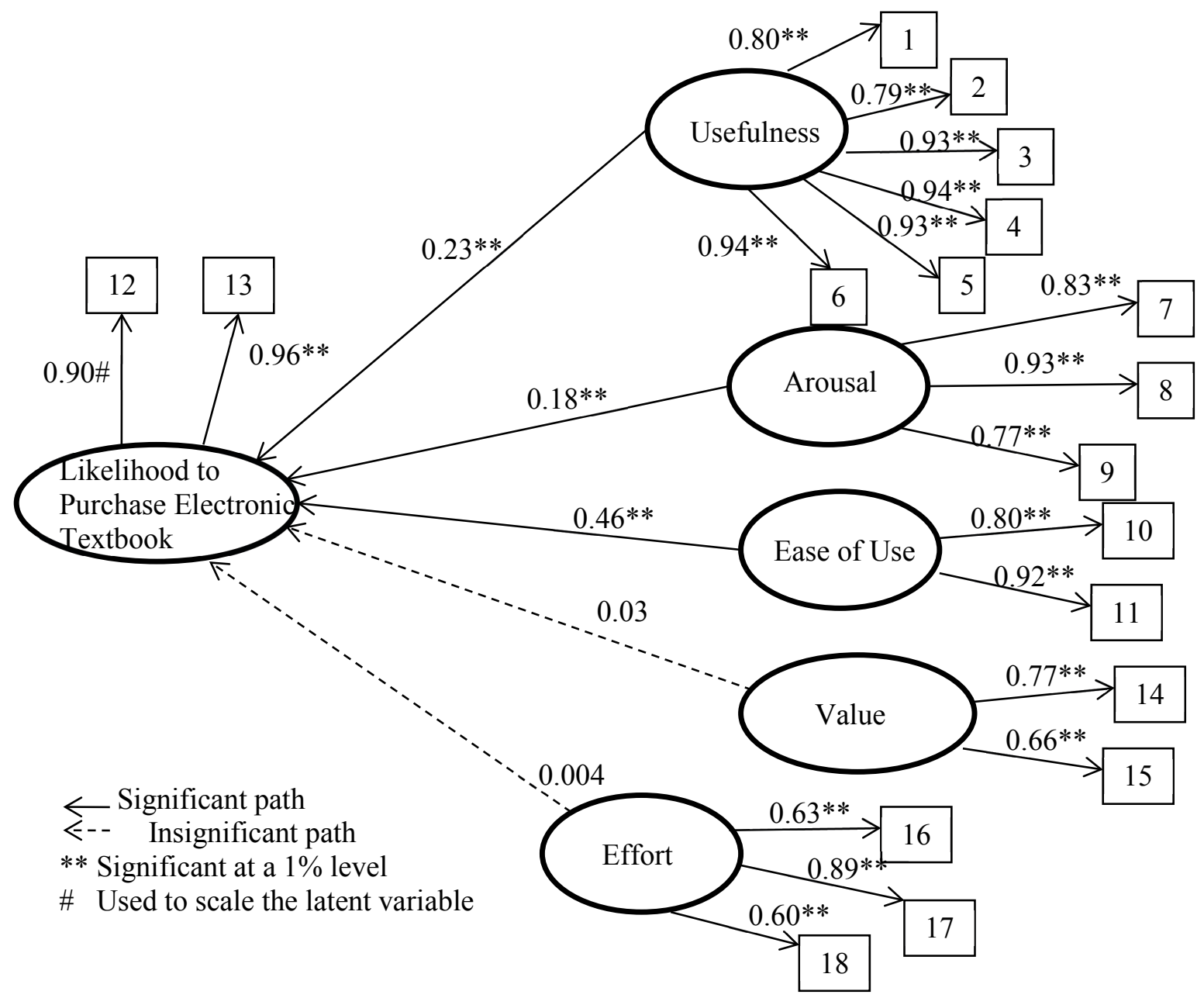

Figure 2: The Standardized Results for the Estimated Model

All the estimated paths between the indicants and their respective measures were statistically significant at a $1 \%$ level. These values ranged from 0.60 to 0.94 and are shown in Figure 2 on the path arrows from the latent constructs to the numbered indicants shown as rectangles. The empirical results for the structural model indicate that usefulness, arousal, and ease of use have significant impacts on students' likelihood to purchase an e-text at the $1 \%$ level of significance. The insignificant paths to likelihood to purchase an electronic textbook were from value and effort.

\section{Discussion}

The empirical results indicate that students' perceptions of e-text usefulness for studying positively impact their willingness to purchase an electronic textbook (H1). The result is intuitively appealing, if this form of a textbook is seen as adding value to their academic performance they will use it, if not they will not. The arousal variable also had meaningful influences on the likelihood to purchase an e-text (H2). In essence, the result indicates that if students' find the use of an e-text to have some interest or meaning (e.g., be stimulating and meaningful) this will influence their willingness or likelihood to purchase an e-text. The final significant variable is ease of use (H3). 
If the electronic textbook is easy for students to use it increases the likelihood they will purchase it.

The meaningful variables found in this study are consistent with results reported by Falc (2013) which surveyed public speaking students regarding their attitudes toward using an e-textbook. One result found in the Falc (2013) study was the importance of an e-textbook helping students with assignments and studying for exams, which is consistent with this study's identified importance of perceived usefulness. Similarly, Falc (2013) found that over half the students reported enjoying using an e-textbook which is consistent with these findings regarding arousal. Finally, Falc (2013) reported students' frustration with using an e-textbook due to problems of layout, readability, and navigation. These results are consistent with our findings regarding the importance of an e-textbook's ease of use.

These results provide some direction to faculty desiring to encourage students' use of e-texts. One would need to provide students evidence that e-text use leads to desired academic outcomes. Similarly, making sure the digital material is easy to use will encourage students' likelihood to purchase e-texts. Finally, students who are interested in or aroused by advanced or new technology are more likely to purchase an electronic textbook. This could be accomplished by selecting electronic textbooks that use the latest technologies or provide students with desired features.

Two variables in the model were not statistically significant, value (H4) and effort (H5). While these results are consistent with those reported by Bennett and Landoni (2005) and Carlson (2005), this lack of significance is intuitively surprising since these measures are cost related and cost is frequently cited as a key driver of e-text adoption. These results may indicate that students who have used or purchased an e-text evaluate the value proposition (i.e., price and quality combination) around a textbook the same whether it is digital or paper-based. As a result, the value measure may not influence the likelihood to purchase an e-text (DeSantis, 2012). In fact, Shepperd, Grace, and Koch (2008) found that college students view e-texts as easy to use but inconvenient. Additionally, the corresponding price reduction relative to a paper text is not sufficient incentive to promote e-text use. Similarly, the effort measure examined students' perspectives on how worthwhile it is to spend time searching for low price textbooks, regardless of format. This measure does not appear to influence students' likelihood to purchase an e-text.

\section{Conclusions}

Given the growing trend of e-texts in education, it is worthwhile to understand what influences students' willingness to purchase electronic textbooks. This research examines the influences of e-text usefulness, arousal, ease of use, value, and effort on students' likelihood to purchase an etext as shown in Figure 1. The research results indicate that the variables of usefulness, arousal, and ease of use significantly and positively impact students' likelihood to purchase an e-text. Knowledge of these variables or factors can help faculty select electronic textbooks that will help encourage student purchase and use of these texts.

Future research should include the use of electronic reader devices and the relationships of value and effort of e-texts. Understanding the type of reader device and the usability of the device would provide further insight into the acceptance of e-textbooks. Connecting user computer experience to device usability could also influence acceptance of e-textbooks in the future. The relationship between value and effort of e-texts would also inform the academic community. Value is the combination of price and e-text quality. Understanding students' perception of value may explore the phenomenon of slow e-text acceptance. Effort, as it relates to e-texts, is the willingness of a student to seek out cost savings in purchasing e-textbooks. With an expanding field of digital sources for textbooks students may be able to expend less effort to save money. 


\section{References}

Baker-Eveleth, L. J., Miller, J. R., \& Tucker, L. (2011). Lowering business education cost with a custom professor-written online text. Journal of Education for Business, 86(4), 248-252.

Baker-Eveleth, L. J., Stone, R. W. \& Pendegraft, N. (2005). Changes in students' perceptions of programming skills using class projects. Journal of Business and Management, 11(1), 25-40.

Bandura, A. (1986). Social foundation of thought and action: A social cognitive theory. New Jersey: Prentice-Hall, Inc.

Bates, R., \& Khasawneh, S. (2007). Self-efficacy and college students' perceptions and use of online learning systems. Computers in Human Behavior, 23(1), 175-191.

Bennett, L., \& Landoni, M. (2005). E-books in academic libraries. The Electronic Library, 23(1), 9 -16.

Birnbaum, B. (2004). The case for online course packs and e-books. Campus Technology's eLearning Dialogue, 26 May. Retrieved March 15, 2012 from http://www.campustechnology.com/news article.asp?id=9468\&typeid=155

Bradshaw, G. L. (2005). Multimedia textbooks and student learning. Journal of Online Learning and Teaching, 1(2), 1-10.

Buzzetto-More, N., Sweat-Guy, R., \& Elobaid, M. (2007). Reading in a digital age: e-books are students ready for this learning object? Interdisciplinary Journal of Knowledge and Learning Objects, 3, 239250. Retrieved from http://www.ijello.org/Volume3/IJKLOv3p239-250Buzzetto.pdf

Carlson, S. (2005, February 11). Online textbooks fail to make the grade. Chronicle of Higher Education, 35. Retrieved March 13, 2006 from Lexis-Nexis.

Cavanaugh, T. (2004). Using electronic texts as the course textbook. In R. Ferdig et al. (Eds.), Proceedings of Society for Information Technology \& Teacher Education International Conference 2009. Chesapeake, VA: AACE, 1113-1117.

Chernev, A. (2005). Feature complementarity and assortment in choice. Journal of Consumer Research, 31, 748-759.

Coleman, G. (2004). E-books and academics: An ongoing experiment. Canadian Library Association Feliciter, 4, 124-125.

Choi, C. Q. (2012). Textbooks come alive. Scientific American, 306(4), 20-20.

d'Astous, A. (2000). Irritating aspects of the shopping environment. Journal of Business Research, 49(2), 149-156.

DeSantis, N. (2012). E-Textbooks saved many students only \$1, a college determines. Chronicle of Higher Education, 58(19), A15-A15.

Dillion, D. (2001). E-books: The University of Texas experience, part 2. Library Hi Tech, 19(4), 350-363.

Falc, E. O. (2013). An assessment of college students' attitudes towards using an online e-textbook. Interdisciplinary Journal of E-Learning and Learning Objects, 9, 1-12. Retrieved from http://www.ijello.org/Volume9/IJELLOv9p001-012Falc831.pdf

Fornell, C., \& Larcker, D. F. (1981). Evaluating structural equation models with unobservable variables and measurement error. Journal of Marketing Research, XVIII, 39-50.

Hair, J., Jr., Anderson, R. E., Tatham, R. L., \& Black, W. C. (1992). Multivariate data analysis: With readings. New York: MacMillan Publishing Company.

Henry, J. W., \& Stone, R. W. (2001). The role of computer self-efficacy, outcome expectancy, and attribution theory in impacting computer system use. Journal of International Information Management, $10(1), 1-16$. 
Hooper, D., Coughlan, J., \& Mullen, M. R. (2008). Structural equation modeling: guidelines for determining model fit. Electronic Journal of Business Research Methods, 6(1), 53-60.

Igbaria, M., \& Greenhaus, J. H. (1992). Determinants of MIS employee's turnover intentions: A structural equation model. Communications of the ACM, 35, 35-49.

Iivari, J. (2005). An empirical test of the DeLone-McLean model of information system success. The Data Base for Advances in Information Systems, 36(2), 8-27.

Kirkwood, A., \& Price, L. (2005). Learners in the twenty-first century: What do we know about students' and experiences of information and communication technologies that will help us design courses. Studies in Higher Education, 30(3), 257-274.

Lai, J.-Y., \& Chang, C.-Y. (2011). User attitudes toward dedicated e-book readers for reading: The effects of convenience, compatibility and media richness. Online Information Review, 35(4), 558-580

Lau, J. (2008). Students' experience of using electronic textbooks in different levels of education. Scroll, $1(1)$.

Liu, Z. (2005) Reading behavior in the digital environment, changes in reading behavior over the past ten years. Journal of Documentation, 61(6), 700-712.

Mogharreban, N., \& Guggenheim, D. (2008). Learning pod: A new paradigm for reusability of learning objects. Interdisciplinary Journal of E-Learning and Learning Objects, 4, 303-315. Retrieved from http://www.ijello.org/Volume4/IJELLOv4p303-315Mogh477.pdf

Noyes, J., \& Garland, K. (2005). Student's attitudes towards books and computers. Computers in Human Behavior, 21, 233-241.

Noyes, J., \& Garland, K. (2006). Explaining student's attitudes toward books and computers. Computers in Human Behavior, 22, 351-363.

Nunnally, J. (1978). Psychometric methods (2nd ed.). New York: McGraw-Hill.

Peek, R. (2012). Textbooks in turmoil. Information Today, 29(5), 26-26.

Rai, A., Lang, S. S., \& Welker, R. B. (2002). Assessing the validity of IS success models: An empirical test and theoretical analysis. Information Systems Research, 13(1), 50-69.

Rainer, R. K., Jr., \& Harrison, A. W. (1993). Toward development of the end user computing construct in a university setting. Decision Sciences Journal, 24(6), 1187-1202.

Ritzhaupt, A. D. (2010). Learning object systems and strategy: A description and discussion. Interdisciplinary Journal of E-Learning and Learning Objects, 6, 217-238. Retrieved from http://www.ijello.org/Volume6/IJELLOv6p217-238Ritzhaupt701.pdf

Schoch, H. P., Teoh, H. Y., \& Kropman, M. (2006). Adopting an electronic text book for a postgraduate accounting course: An experience study. Australasian Journal of Educational Technology, 22(2), 166188.

Shepperd, J. A., Grace, J. L., \& Koch, E. J. (2008). Evaluating the electronic textbook: Is it time to dispense with the paper text? Teaching of Psychology, 35(1), 2-5.

Stone, R. W. \& Baker-Eveleth, L. J. (2013). Students' intentions to purchase electronic textbooks. Journal of Computing in Higher Education, 25(1), 27-47.

Thomas, S. E. (2007). Another side of the e-book puzzle. Indiana Libraries, 26(1), 39-45.

Thurston, J. (2000). Screenreading: Challenges of the new literacies. Information Technology, Education and Society, 1(1). 39-55.

Tomassini, J. (2012). Educators weigh e-textbook cost comparisons. Education Week, 31(30), 1.

Tsiotsou, R. (2006). The role of perceived product quality and overall satisfaction on purchase intentions. Journal of Consumer Studies, 30(2), 207-217. 
Weisberg, M. (2011). Student attitudes and behaviors towards digital textbooks. Publishing Research Quarterly, 27(2), 188-196.

Young, J. R. (2009). 6 Lessons One Campus Learned About E-Textbooks. Chronicle of Higher Education, 55(39), A18-A18.

\section{Biographies}

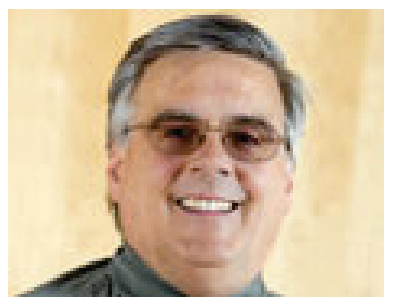

Robert W. Stone (Ph.D. Purdue University) is currently a Professor of Accounting \& Information Systems at the University of Idaho in Moscow, Idaho. His teaching interests are Accounting Information Systems, Systems Analysis and Design, and Managerial Accounting. His research interests include user adoption and continued use of information system and the impacts from the use of information system. Professor Stone has published numerous research works, some of which have appeared in Computers in Human Behavior, the International Journal of Information Security and Privacy, Review of Accounting Information Systems, Journal of Academic Administration in Higher Education, Journal of Business Research, Behaviour \& Information Technology, and Information Resources Management Journal.

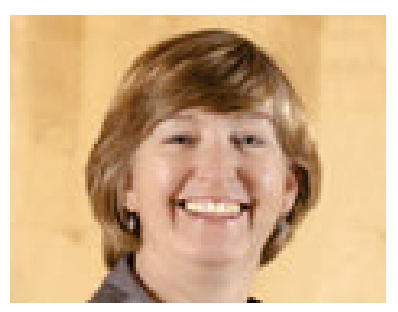

Lori J. Baker-Eveleth (Ph.D. Washington State University), Associate Professor of Information Systems at the University of Idaho.. Her research interests focus on user acceptance of technology, communities of practice, and social media. She has published research in the Journal of Information Systems Education, EDUCAUSE, Behaviour \& Information Technology, Decision Sciences Journal of Innovative Education, Journal of Business and Management, and Computers in Human Behavior. 